\title{
AZ AKADÁLYMENTES TURIZMUS ÉLMÉNY ÉS VENDÉGELÉGEDETTSÉG SZEMPONTÚ MEGKÖZELÍTÉSE A SZÁLLODA SZEKTORBAN
}

\author{
Horváth Gergely \\ Pécsi Tudományegyetem, Közgazdaságtudományi Kar, Gazdálkodástani Doktori Iskola, PhD \\ hallgató,gerisson21@gmail.com
}

DOI: $10.15170 /$ TVT.2021.06.01.06

\begin{abstract}
Absztrakt
Manapság az akadálymentes turizmus a különböző országokban egyre nagyobb szerepet kap, a turisztikai szervezetek, és a turisztikai szakemberek is növekvő figyelmet fordítanak rá. A fogalmi határai mára már kiszélesedtek, ami azt jelenti, hogy egyre több szempontból lehet megközelíteni a témát. Nagyon sokan rendelkeznek a mai világban valamilyen fogyatékossággal, ami kihat egész életükre, így az utazásaikra is. A különböző országokban, így hazánkban is elmondható, hogy a fogyatékos emberek turisztikai lehetőségei, különböznek a „normális” emberekéhez képest. Jelen szempontokat figyelembe véve, a tanulmány célja, hogy az akadálymentes turizmusnak, a szállodai élményhez és vendégelégedettséghez füződő kapcsolatáról átfogó képet mutasson be annak érdekében, hogy az eddigi szemléletmódjaihoz képest, egy új szemszögből lehessen megismerni a témát. A fenti szemponton túl a tanulmány bemutatja az akadálymentes turizmus életminőség és fenntarthatóság szempontú megközelítését is, amely szintén kapcsolatba hozható a szállodai élmény és vendégelégedettség témakörével. A tanulmányból kiderül, hogy az akadálymentes turizmus a mai világban nagyon fontos az emberek számára. Véleményem szerint az akadálymentes turizmusnak a legnagyobb problémája szolgáltatások esetén a szubjektivitás, ami azt jelenti, hogy a vállalatok nem tudnak egyidejüleg minden „sérültet” elvárásaik tekintetében teljes mértékben kielégíteni, ezért fontos a célcsoport megfelelő kiválasztása. Úgy gondolom, hogy a mozgássérült fogyasztóknak vendégelégedettségi és minőségi mérése is fontos a vállalatok számára, ugyanis lényeges információkat adhat a vállalati vezetőknek a termékek és szolgáltatások gyengeségeiről, erősségeiről (a megfelelő célcsoport kiválasztása érdekében) a jövőbeni nagyobb sikerek érdekében.
\end{abstract}

Kulcsszavak: akadálymentes turizmus, élmény, vendégelégedettség, életminőség, fenntarthatóság 


\begin{abstract}
Today, barrier-free tourism is playing an increasingly important role in different countries, in which tourism organizations and professionals also play an important role. Its conceptual boundaries have now widened, which means that the topic can be approached from more and more perspectives. A lot of people in today's world have some form of disability that affects their entire lives, including their travels. Thus, in different countries, it can be said in Hungary that the tourist opportunities of people with disabilities are different from those of a "normal" person. Considering the present aspects, the aim of the study is to present a comprehensive picture of the relationship between barrier-free tourism, hotel experience and guest satisfaction in order to get to know the topic from a new perspective compared to its previous approaches. In addition to the above aspect, the study also presents an approach to accessible tourism in terms of quality of life and sustainability that can also be related to the topic of hotel experience and guest satisfaction. The study shows that barrier-free tourism is very important for people in today's world. In my opinion, the biggest problem with barrier-free tourism in terms of services is subjectivity, which means that companies cannot fully meet all their "injured" expectations at the same time, so it is important to choose the right target group. In my opinion, measuring customer satisfaction and quality for consumers with disabilities is also important for companies, as it can provide relevant information to company leaders about the weaknesses and strengths of products and services (in order to select the right target group) for greater future success.
\end{abstract}

Key words: barrier-free tourism, experience, guest satisfaction, quality of life, sustainability 


\section{Bevezetés}

Az akadálymentesség fogalmi határai mára már kiszélesedtek (ZSARNÓCZKY 2018). Mindenhol természetesnek kellene lennie annak, hogy a fogyatékkal élő embereket az épek elfogadják, ami azt is jelenti, hogy a körülményeiket úgy kell kialakítani, hogy semmilyen módon ne éreztessük velük azt, hogy korlátozva vannak. Ha nem a szó szoros értelmében értelmezzük az életvitelt (pl.: a családon belüli elfogadást, a lakáson, házon belüli életvitelt), akkor ebbe beletartoznak az egyes infrastrukturális dolgok is pl. a közlekedés, munkavállalás vagy az utazás (GONDOS 2017).

E téma, valamint a fenti szempontok új kutatási kérdéseket vethetnek fel, ezért azt gondolom, hogy érdemes lenne tisztázni a fogyatékossággal kapcsolatos fogalmakat. A fogyatékosság egy olyan fizikai vagy mentális állapotot jelent, amelyek valamilyen testi vagy szellemi károsodásra utal, ami „akadályokat” idéz elő a mindennapi életvitelünk során. A fogyatékkal élő embereknek sok csoportja van, amelyekböl jelen esetben csak néhányat sorolok fel. Ebbe a kategóriába tartoznak pl. a mozgáskorlátozottak, a vakok vagy gyengén látók, a siketek vagy halláskárosultak, a fejlődési rendellenességgel, értelmi és tanulási zavarokkal küszködök, a müvégtagokkal rendelkezők, akik valamilyen allergiával és/vagy valamilyen egyéb érzékenységgel rendelkeznek stb. (ZSARNÓCZKY, 2017). Az orvosi szempontokat figyelembe véve a szakemberek szerint létezik veleszületett fogyatékosság, valamint az emberi gének rossz müködésének következtében kialakult fogyatékosság. Utóbbi az emberi szülési/születési fázis (pl. terhesség egyes fázisai alatt, vagy a születés után nem sok idő elteltével alakul ki újszülött korban) valamelyik stádiumában alakulhat ki, vagy életünk valamely szakaszán ,szerzett/kapott” fogyatékosság, amely külső okra vezethető vissza pl. balesetre. (ZSARNÓCZKY 2018)

A turizmusban az emberek folyamatosan utaznak a világ különböző pontjaiba pihenés céljából. Ezen utazások során különböző igényeket támasztanak az őket fogadó területtel szemben. Az igényeik kielégítéséhez köthető szolgáltatások közé sorolhatók a közlekedési-, szállás- és étkezési lehetőségek mellett a szabadidő változatos eltöltési lehetőségein túl az orvosi-, kereskedelmi-, pénzügyi- és egyéb szolgáltatások (LENGYEL, 2008). Mindent együttvéve azonban a turista az utazásai során elsődlegesen élményekre vágyik, élményszerzés céljával kel útra. (MICHALKÓ, 2012) A modern turisztikai termékfejlesztésnek is az az egyik legfontosabb kérdése, hogy innovatív megoldásokkal hogyan lehet a meglévő adottságokra építve a legnagyobb élményhatást biztosítani. (OROSZI - GONDA, 2016) Manapság egyre inkább az élmény a középpontba kerülő fogalom a turizmus minden területén, a szállodaipartól kezdve egészen a turisztikai desztinációkig. Ha az emberek/turisták pozitív élményt kapnak valamilyen utazás következtében, akkor azok az élmények pozitív irányba fogják befolyásolni az emberben kialakuló különböző érzéseket, mint pl. a boldogságot. Az élmény olyan szempontból is fontos, hogy ha egy turista az utazása során sok pozitív irányú élményt szerez, akkor ki fog benne alakulni egyfajta elégedettség az adott desztinációval, szálláshellyel, szolgáltatásokkal kapcsolatban. Viszont azoknak az embereknek, akik valamilyen fogyatékkal rendelkeznek, azoknak eltérő igényeik vannak a mindennapi életvitelükhöz kapcsolódóan. Ha ezeket az igényeket figyelmen kívül hagyjuk, az azt fogja eredményezni, hogy ellehetetlenítjük az utazási vagy nyaralási lehetőségét a fogyatékkal élő embereknek. (ERNSZT 2019) Ezek a szempontok a turisztikai szolgáltatásokat nyújtó vállalkozásokat is kihívások elé állítják, annak érdekében, hogy a speciális igényeknek meg tudjanak felelni. Ebbe sok minden beletartozik pl. a közlekedés, vagy a szálloda épülete kívül-belül akadálymentessé történő generálása. Sok esetben nem figyelnek arra a vállalatok, hogy a környezetük ne csak kívülről, hanem belülről is könnyen megközelíthető legyen, ezért sok esetben a mozgáskorlátozottak egy kísérővel utaznak segítségként. Ezen túlmenően, szintén megjelenik a fogyatékos emberekhez való emberi (személyzeti) hozzáállás, amelyet a szervezetek különböző tréningek segítségével taníttatnak meg, hogy hogyan kell bánni egy fogyatékkal élővel azért, hogy ö is teljes értékü embernek érezhessék magukat a többi között, hogy ő is részt vehessen adott esetben a szálláshely vagy nevezetesség, vagy ország adta programlehetőségeken. (ERNSZT 2019, GONDOS 2017) 
Korábban már több tanulmány is készült az akadálymentesség és az utazási szokások kapcsolatáról, az akadálymentesség és életminőség kapcsolatáról viszont kevesebb. Ez lényeges szempont, ugyanis fontos megismerni, hogy mik azok, amelyek meghatározzák a fogyatékkal élő emberek utazási döntéseit, ami kihat a boldogságukra és az életminőségükre. (GONDOS 2017) Felmerül a kérdés, hogy a turizmus szektorban elég-e az akadálymentességet az utazási szokások tükrében elemezni vagy szükséges-e új megközelítések ismertetése. A válasz egyértelmüen igen, (FARKASPETYKÓ 2019) ezért a tanulmány célja, hogy egyrészröl bemutassa az akadálymentes turizmus élmény és vendégelégedettség szempontú megközelítéseit, másrészről pedig, hogy bemutassa az életminőség és fenntarthatóság szempontú megközelítését is. Jelen tanulmány szekunder alapú kutatásból ered, tehát a különböző hazai, illetve nemzetközi szakirodalmakon alapul.

\section{Az akadálymentes turizmus élmény és vendégelégedettség szempontú megközelítése}

Az akadálymentes turizmus célja, hogy minden fogadóterület, desztináció, valamint turisztikai termék vagy szolgáltatás mindenkinek elérhetővé váljon függetlenül attól, hogy rendelkezik-e az ember valamilyen fogyatékos megbetegedéssel vagy nem (AKADÁLYMENTES TURIZMUS).

A mai világban a turisztikai és szállodai szolgáltatásokhoz kapcsolódó kereslet átalakult. A különböző generációs csoportok más és más elvárásokkal rendelkeznek, amely azt is jelenti, hogy az élmény teljesen különböző értéket képvisel az egyes életkori szegmensekben. (CSAPÓ ET AL. 2018) További jelentősége, hogy az eltérő élménytípusok eltérő élménytényezőket is jelentenek. Ezek a szokások, amelyeket a különböző szegmensek generálnak, nagymértékben befolyásolják azt is, hogy a vállalatoknak milyen marketing- és menedzsment típusú tevékenységet kell folytatniuk itthon és külföldön. (GROTTE - KULCSÁR - 2018). Az idegenforgalmi vállalatok a termékeiket és szolgáltatásaikat sokszor csomagként értékesítik. Jellemzően ezek a csomagok egy fö szolgáltatás vagy termék köré épülnek, amelyhez kiegészítő termékek vagy szolgáltatások is tartozhatnak. A kialakított termékek, illetve szolgáltatások minősége a vállalatoktól függ. Minden egyes vásárlói tapasztalat befolyásolja az idegenforgalmi célterület képét, ezért nagyon fontos, hogy a vállalatok jó minőségü termékeket hozzanak létre. (STICKDORN - ZEHRER, 2009)

$\mathrm{Az}$ egyes turisztikai célterületek más-más módon segítik a fogyatékkal élő emberek utazását. Vannak olyan területek, ahol egyedi ajánlatot kínálnak a vállalatok a fogyatékkal élőknek, viszont vannak olyanok is, akik megkülönböztető jegyként használják ki ezt a piaci rést. Természetesen vannak olyan célterületek és vállalatok is, akik nem foglalkoznak az akadálymentesítés témakörével. (DARCY -GONZÁLEZ -VILA 2015).

Fontos, hogy ha fogyatékkal élőkről beszélünk, akkor próbáljuk meg az utazásukat a számukra szükséges feltételek teljesítésével megkönnyíteni. Ez már nem csak emberiességi, etikai, erkölcsi feladat, de egyben jogi és gazdasági szempontból is fontos. (GONDA-RAFFAY 2020, BUHALIS ET AL 2012). Azonban az emberek a fogyatékosságuktól függően más-más igényekkel rendelkeznek, ezért nem lehet őket egységesen kezelni. Léteznek olyan problémák, amelyeket minden utazó átélhet utazása során, s vannak olyanok is, amit csak egy-egy szegmens érezhet akadályként (COLES - SHAW 2004, BUHALIS -MICHOPOULOU 2013, DARCY MCKERCHER 2018). Az akadálymentes turizmus kialakítása nem egyenlő a fizikai akadálymentesítéssel: az a célterület, amelyet teljesen akadály mentesítenek, egyrészt sokkal nagyobb élményben tudja részesíteni az embert, másrészt ezen túlmenően növeli az emberi méltóságát is, ami azt jelenti, hogy érzékeltetik, hogy a sérült emberek is fontosak a célterületnek és a vállalatnak. Ez természetesen növelheti az élmény és elégedettség kialakulását is. A célterület különlegességeinek megismerése a fogyatékkal élöknek is ugyanolyan fontos, mint az egészséges embereknek. Ennek kialakításában kiemelt kapnak a turisztikai vállalatok, amelyeknek célja, hogy mindenki számára elérhető, hozzáférhető élményeket nyújtson. (DARCY -DICKSON 2009). Ennek kialakításában a személyzetnek is fontos szerepe van. Fontos azt megtanulniuk, hogy hogyan kell bánni és kommunikálni a fogyatékkal élő vendégekkel. Ezt különböző tréningeken tudják elsajátítani. (GARZÓN et al.2015). Lényeges, hogy a személyzet megfelelő empátiával és odafigyeléssel kezelje le a vendéggel kapcsolatos szituációkat (KOVÁCS -KOZÁK 2016). 
A kérdés sokszor az, hogy a célterületek és a szálláshelyek mennyire készülnek fel a fogyatékkal élö emberek fogadására: pl. a vakvezető kutyák fogadása a szálláshelyeken stb. (RICKY 2018). A fogyatékkal élőknek egy utazás a szürke hétköznapokból való kiszakadást jelentheti, ebben segíthet nekik a célterület és a szálláshely adta élmények megtapasztalása, a társadalomba való könnyebb beilleszkedés, és a másokkal való kapcsolatteremtés (GÁLNÉ KUCSÁK 2008). Több vizsgálat is kimutatta, hogy Magyarországon, nincsenek teljes mértékben felkészülve a célterületek és a szálláshelyek a fogyatékkal élők fogadására, ezáltal az ember fogyatékossága valamelyest megakadályozza az utazási tervek és élmények megvalósítását. (ERNSZT 2019)

Manapság a vállalatoknak fontos, hogy fogyasztóik és ügyfeleik elégedettek legyenek a tevékenységeikkel. Az elégedettségnek több szerepe is van egy vállalat életében. Egyrészt lényeges információkat ad a vállalati vezetőknek a problémás folyamatok fejlesztéséhez, másrészt tájékoztat a jövőbeni sikerekről vagy kudarcokról.

BÁTOR (2007) összeszedte azokat az előnyöket, amelyek a fogyasztói elégedettség pozitív „következményeként” jelennek meg egy vállalat életében. Jelen esetben csak néhány kerül említésre, amelyek a következőek:

1. Ha nő az elégedettség, akkor javul a vállalat hírneve,

2. Nőhet a pozitív irányú szájreklám, ami szintén emeli a vállalat hírnevét

3. Lehetőség nyílik arra, hogy kialakuljon, illetve emelkedjen a vevők lojalitása,

4. A vevők nem pártolnak át a versenytársakhoz egy jobb ajánlat következtében, így csökken a „szervezetet elhagyók” aránya,

5. Csökken a fogyasztók árérzékenysége a termékek, illetve a szolgáltatások iránt,

6. Az elégedett vásárlók megfizetik a kapott további szolgáltatásokat,

7. Emelkedik a cég jövedelem termelése,

8. Nő a piacon belüli részesedése az adott iparágon belül. (BÁTOR, 2007).

Ha a fogyasztó elégedett lesz a szolgáltatóval, akkor ezáltal pozitív jellegü „következményként” előbb vagy utóbb ki fog alakulni a szolgáltatóval szemben a vendégek lojalitása. Más szóval ez elkötelezettséget, hüséget jelent a fogyasztónak a vállalat iránt. A lojális fogyasztóra jellemző, hogy mindig ugyanazt a szolgáltatót választja vásárlás céljából, másoknak is ajánlja a szolgáltató termékeit, szolgáltatásait, és mindig pozitív irányú kapcsolatot tart fenn a szolgáltató felé (KANDAMPULLY-SUHARTANTO, 2000).

FORNELL (1992) is úgy gondolja, ha magas az ügyfél elégedettsége, akkor növeli az ügyfél hüségét a vállalat iránt. Ez azt is jelenti, hogy az ügyfelek kevésbé hajlamosak az elvándorlásra. Ezt a nézetet folytatta ANTON (1996) is, aki azt mondta, hogy az elégedettség pozitív irányba befolyásolja a fogyasztó általi további vásárlási szándékot, ami tovább növeli a termék vagy szolgáltatás iránti hüséget és a vállalat jövedelmezőségét. KARAKASNÉ MORVAY (2014) szerint abban az esetben, ha a vállalatoknak nem sikerül teljesíteni megfelelően a vevők általi elvárásokat, a fogyasztók részéről ki fog alakulni egy negatív irányú „következmény”, amely gyakorlatilag a vállalattól történő vevői elvándorlást, lemorzsolódást jelenti. MESTER (2005) meggyőződése, hogy a vállalatoknak elsődleges célja az, hogy minél hosszabb ügyfél életciklust alakítsanak ki, hogy ezáltal kialakuljon a lojalitás az ügyfélben. MESTER (2005) nézete alapján elengedhetetlen, hogy a vállalat pontosan tudja, melyik szegmenset kell megcélozni tevékenységeikkel, hogy ezzel is csökkentsék azon szegmensek számát, akik hajlamosak az elvándorlásra. Véleménye szerint folyamatosan szükséges vizsgálni a vevői elégedettséget, és ha van, akkor az ügyfélpanaszokat is rendszeresen meg kell vizsgálni. Ezen vizsgálatok eredményeit a vállalati menedzsment által beépítik a további vállalati tevékenységükbe, hogy ne forduljon elö még egyszer, hogy ugyanolyan hibákat követnek el, mint korábban. 
BANSAL-GUPTA (2001) szerint az elégedettség az egyetlen módja annak, hogy a vállalatok fenntartható versenyelönyt alakítsanak ki a versenytársaikkal szemben. A fogyasztói hüség kiépítéséhez szükséges stratégiai követelmény, hogy a vállalat a megfelelö ügyfélkört válassza ki, illetve építse ki, amelyekre az alábbiak jellemzők:

1. Fókuszban a legfontosabb ügyfeleknek kell állniuk

2. Szükséges a szorosabb viszony kiépítése a kiemelt ügyfelekkel

Tehát összességében azt gondolom, hogy látható a párhuzam a két téma (akadálymentes turizmus és az élmény és vendégelégedettség között.

\section{Az akadálymentes turizmus életminőség és fenntarthatóság szempontú megközelítése}

Az akadálymentes turizmus és az életminőség kapcsolatára utaló fogalmakat sokan szerették volna már tisztázni, de eddig még nem sikerült egy egységes fogalomrendszert kialakítani a különbözö megközelítések miatt. VEENHOVEN (1996) szerint: az életminőséget több szempont befolyásolja, amelyek között megtalálható gazdasági, politikai és társadalmi szempontok is. DIENER ET AL. (1995) véleménye is hasonló elödjéhez képest, annyi különbséggel, hogy a fent nevezett három szempontot kiegészítette az életindexxel. (pl. felsőfokú képzésben résztvevők aránya, jövedelemegyenlőség). Diener véleménye alapján: a szubjektív életminőség az emberek saját életükre történő értékelésére utal, amelybe beletartozik pl. a boldogság, az életükkel való elégedettség, a kellemes és kellemetlen érzések. (DIENER, E.-DIENER, M. 1995) (DEMOS MAGYARORSZÁG ALAPÍTVÁNY 2007). Az életminőség mérésére három lehetőség van:

1. Objektív mutatókkal mérjük az életminőséget,

2. Szubjektív mutatókkal mérjük az életminőséget (pl., egészségi állapot, anyagi helyzet stb.),

3.Mindkét mutatóval mérjük az életminőséget (DEMOS MAGYARORSZÁG ALAPÍTVÁNY 2007).

$\mathrm{Az}$ életminőséget sok tényező befolyásolja pl., anyagi helyzet, emberi kapcsolatok, egyén személyisége, korosztály, település, faji hovatartozás stb. A fogyatékossággal élőket is jelentősen befolyásolják ezek a tényezők. Az ép embereknél sokszor előfordul, hogy elöítéletekkel rendelkeznek a fogyatékkal élőkkel szemben, ezért másként viszonyulnak hozzájuk. Amikor akadálymentes környezetet szeretnénk kialakítani, akkor elsősorban a kerekesszékkel közlekedők igényeit vesszük figyelembe, hogy megfelelö környezetet tudjunk kialakítani, oly tekintetben, hogy ülőhelyzetből is könnyen kihasználhatóvá tegyük a teret (POLINSZKY 1997). Ezen túlmenően szükséges kapaszkodók kihelyezése is a könnyebb mozgás érdekében. Ez azért is fontos, mert ezek a „segítségek” nem csak a kerekesszékkel közlekedőket segítik, hanem adott esetben az ép embereket is pl. az idősebbeket vagy a családokat, ahol kisgyerek van. Ha a fogyatékkal élők a turizmusban részt tudnak venni (akár egy utazás formájában), akkor már az is egy életminőséget javító tényezőnek számít (MCKERCHER ET AL. 2004). A fogyatékossággal élők manapság egyre gyakrabban jelennek meg a turizmusban. Turisztikai aktivitásuk nem kisebb, mint az egészséges embereké. Ezt támasztja alá egy, a közelmúltban lebonyolított kérdőíves kutatás is. (GONDA RAFFAY 2020, GONDA-CSAPÓ 2019). Ez annak is köszönhető, hogy a turisztikai szervezetek is egyre többet foglalkoznak ezzel a szegmenssel. A fogyatékkal élök nem egyedül utaznak, hanem általában egy kísérővel, aki segítenek nekik, ha kell. Egyre több hotel alakít ki mozgássérülteknek alkalmas szobát, továbbá egyre több vonzerőt is, ami segíti a mozgássérültek utazásba és élménybe való részvételét. A szálláshelyek esetében a legnagyobb problémát a kivitelezés jelenti (pl. parkoló kialakítása, villanykapcsolók, kapaszkodók rossz magasságban történő elhelyezése stb.). Nemzetközi és hazai példával is találkozhatunk az akadálymentesség maximális kialakítására. Pl. az Egyesült Államokban már a turisztikai vonzerők megközelíthetőségén is dolgoznak. Hazánk egyik szállodájában, a Hotel Pandában kiemelt figyelmet fordítanak a megváltozott munkaképességüekre, ahol az a cél, hogy nagyobb esélyük legyen a sérült embereknek az életben való boldogulásra. Ezért a szálloda személyzetének zöme is mozgássérült (95\%) 
A szobák egy részét mozgássérültek fogadására rendezték be, így nemcsak a mozgássérültek, hanem a kevésbé egészségesek, és az idősebbek is könnyebben használhatják. A fogyatékos vendégek lojálisabbak tudnak lenn az adott helyhez, amit megszeretnek, sokszor az átlagosnál négyszer hosszabb ideig maradnak, sok pénzt költenek el pihenésük során. (a külföldiek mindenképp). (GONDOS 2017). MICHALKÓ (2003) szerint a turizmus fenntarthatósága kettős, ami azt jelenti, hogy a vonzerők megőrzését úgy kell megoldani, hogy közben biztosítsuk a turisztikai szolgáltatók sikerességét. A turizmusfejlesztéshez és a fenntarthatósághoz viszont szemléletváltásra van szükség, mind a fogyasztói és vendégoldalról, mind pedig szolgáltatói oldalról nézve. A fogyatékossággal élőknek az esélyegyenlőséget jelenti, ha egy szolgáltatást akadálymentesen igénybe tudnak venni.Az utazás megtervezéséhez nagyon fontos a megfelelő információk megléte is. Kutatások megállapították, hogy a fogyatékossággal élők hosszabb ideig tervezik az utazásukat, mert sok esetben nem rendelkeznek megfelelő mennyiségü és minőségü információval a szolgáltatásokról. Tehát elmondható, hogy a fenntarthatóságot és az akadálymentesítést az ember és a környezet kapcsolja össze. (FARKAS-PETYKÓ 2019) Véleményem szerint a téma ilyen fajta kifejtésénél is megjelenik valamelyest az élmény és vendégelégedettség szempontú megközelítést, amely a tanulmány központi mondanivalója.

\section{Konklúzió, összegzés}

A tanulmányomban arra törekedtem, hogy az akadálymentes turizmus élmény és vendégelégedettség szempontú megközelítésével átfogó képet mutassak be. Ezen túlmenően a tanulmányom részét képezte az akadálymentes turizmus életminőség és fenntarthatóság szempontú megközelítése, amelyből kiderül, hogy szintén kapcsolatba hozható a szállodai élmény és vendégelégedettség témakörével. ERNSZT ET AL (2019) véleménye alapján a mozgássérültek számos problémával találkoznak mindennapi életvitelük során. Ezek közé tartozik pl. a közlekedés. (több alacsonypadlós jármüre lenne szükség, megfelelö útburkolatok festése stb.). Itt is kiderült, hogy ugyanúgy, mint a „normális” elégedettség eléréséhez, elengedhetetlen a szívélyes emberi tényező megléte, ami nemcsak a desztinációban, hanem a szálláshelyen is nagyon fontos. Az desztinációs látványosságok elérhetősége nagyon fontos ahhoz, hogy a mozgássérültek meg tudják közelíteni. A legtöbb mozgássérült családostul utazik, ahol a család jelenti a segítséget a mindennapokban. Nagyon sokat segítene egy ott lakó vagy élő „segítő személy” jelenléte azokon a területeken, amelyeket gyakrabban látogatnak a vendégek, ahhoz, hogy a fogyatékkal élők teljesen élvezni tudják nyaralásukat. (GÁLNÉ, KUCSÁK 2008). Sokszor nem csak a közlekedést kell megoldani, hanem a desztinációs látványosságok és szálláshelyek akadálymentesítését is. Fontos lenne a közösségi közlekedés akadálymentesítése, melyet természetesen befolyásol a fogyatékosság fajtája pl. vak vagy siket az ember. A mozgássérült személyek az épületekbe, zárt terekbe való bejutást kerekesszékkel tudják csak megoldani, a hallássérült személyeknek fény-és hangjelzésekre, illetve jeltolmácsra lenne szükségük. A látássérült személyek számára kiemelkedően fontos, hogy a különböző olvasmányos feliratokat (pl. szállodai helységeket jelző és útba igazító táblák) nagy méretben, élénk színekkel lássák, valamint nem utolsó sorban hanggal történő irányításra, hangos tájékoztatásra is szükség lehet. A fizikai akadálymentesítés mellett lényeges a „lelki akadálymentesítés” is. Ennek formálása egyrészt a turisztikai szervezetek, másrészt a fogyatékkal élők szemléletétől függ. Szükséges lenne egy olyan adatbázis kialakítása, ahol fellelhető minden olyan turizmushoz kapcsolódó helyszín, látványosság és szálláshely (a fentnevezett speciális igényeknek megfelelően), ahol a speciális helyzethez alkalmazkodnak a turisztikai szervezetek. (MOTIVÁCIÓ ALAPÍTVÁNY ÉS A REVITA ALAPÍTVÁNY KUTATÓMÜHELYE 2009). Ennek kialakításához szükséges maga a fogyatékkal élők véleménye, amely nem csak egyszeri véleményeken alapszik, hanem folyamatos egyeztetéseken. (LYU 2017, ERNSZT ET AL 2019). 
Véleményem szerint a szálláshelyek csak részben vannak felkészülve a mozgássérültek fogadására. (Bár megvan az autós parkoláshoz szükséges mozgássérült útburkolati jel, illetve a szobákban lévő kapaszkodók a mosakodáshoz, viszont a további szempontok, pl. a szállodai szekrények és a recepciós pultok magassága, vagy a liftek szélessége és nagysága a tolókocsi méreteihez képest nem megfelelő, ezen kívül hangjelzés sincs a liftekben a tájékozódáshoz, stb.) A fenti szempontok is azt jelzik, hogy érdemes lenne ezzel a szegmenssel részletesebben foglalkozni. A mozgássérültek egy évben akár többször is utaznak, és többnyire ugyanazokat a szervezeteket keresik fel, nem úgy, mint az egészségesek. Sajnos a mai világ helyzetképe azt mutatja, hogy egyre nagyobb lesz a mozgássérültek száma, ezért fontos, hogy a turisztikai szervezetek tudják fogadni ezeket a speciális igényü embereket. Ugyanolyan bánásmód szükséges a mozgássérülteknek, mint az egészségeseknek, a lényeg, hogy ne érje őket hátrányos megkülönböztetés állapotukból kifolyólag. A mozgáskorlátozottak is ugyanúgy, mint a többiek szeretnek új helyszíneket felfedezni, ezért sokszor nem riadnak vissza az akadályoktól sem. (GONDOS 2017)

A fenti sorok véleményem szerint jól tükrözik a mai helyzetképet a mozgássérültekkel kapcsolatban. Úgy gondolom, további kutatási irányként lehetne egy turisztikai desztinációval, annak látnivalóival és szálláshelyeivel egy megvalósítási tanulmányt csinálni a mozgássérültek véleményeit is figyelembe véve, hogy legyen egy példa arra, hogy hogyan kell(ene) kinéznie egy mozgássérültek fogadására alkalmas desztinációnak. Nemzetközi és egy-egy hazai példa is van, akik jobban segítik a mozgássérültek utaztatását, viszont nem biztos, hogy ők tapasztalati szemmel nézve alakították ki a szükséges intézkedéseket.

\section{Irodalomjegyzék}

ANTON, J. (1996): Customer Relationship Management: Making Hard Decisions with Soft Numbers, Upper Saddle River, Prentice-Hall, New Jersey

BANSAL, S. - GUPTA, G. (2001): Building Customer Loyalty Business-to-Business Commerce. In J. N. Sheth A. Parvatiyar \& G. Shainesh, (eds)., Customer Relationship Management. Tata McGraw-Hill, New Delhi,

BÁTOR, A. (2007): A vevőelégedettség és a lojalitás kapcsolata a kereskedelmi bankok szférájában a lakossági piacon. PhD értekezés. Nyugat-Magyarországi Egyetem Széchenyi István Gazdasági Folyamatok Elmélete és Gyakorlata Doktori Iskola. Sopron. pp. 1-197

BUHALIS, D. - MICHOPOULOU, E. (2012): Information provision for challenging markets: The case of the accessiblity requiring market in the context of tourism. Information and Management 50, pp. 229-239.

COLES, T. - SHAW, G. (2004): Disability, holiday making and the tourismindustry in the UK: a preliminary survey. Tourism Management 25: pp. 397-403.

CSAPÓ, J. - GERDESICS, V. - GONDA, T. -RAFFAY, Z.- TÖRÖCSIK, M. (2018): Turizmus: a magyar lakosság turizmussal kapcsolatos beállítódása generációs szemléletű vizsgálattal - országosan reprezentatív személyes $(n=2001)$ és online $(n=1085)$ megkérdezés, fókuszcsoportos viták eredményei, Pécsi Tudományegyetem Közgazdaságtudományi Kar, Pécs,

DARCY, S. -DICKSON, T. J. (2009): A whole-of-life approach to tourism: The case for accessible tourism experiences. Journal of Hospitality and Tourism Management16: pp. 32-44.

DARCY, S. - GONZÁLEZ, E. A. - VILA, T. D. (2015): Competing for the disability tourism market -A comparative exploration of the factors of accessible tourism competitiveness in Spain and Australia. Tourism Management47: pp. 261-272.

DARCY, S. - MCKERCHER, B. (2018): Re-conceptualizing barriers to travel by people with disabilities. Tourism Management Perspectives 26, pp. 59-66

DEMOS MAGYARORSZÁG ALAPÍTVÁNY (2007): Az életminőség fogalmán túl.Elméletek, módszerek és gondolatok az életminőség kapcsán. 
DIENER, E.,- DIENER, M. (1995): Cross-cultural correlates of life satisfactions and self-esteem. Journal of personality and Social Psychology, 68. pp.653-663.

ERNSZT, I. -KELLER, K. -PÉTER ERZSÉBET -TÓTH-KASZÁS, N. (2019): „Amikor a vándorbot színe fehér, az utazó kerekesszékben ül" -az akadálymentes turizmus egyes kérdéseiről, Turisztikai és vidékfejlesztési tanulmányok, 4(3) pp.78-91

FARKAS, J. - PETYKÓ, CS. (2019): Utazás az akadálymentesség, a fogyatékosság és a fenntarthatóság multidiszciplináris és bölcseleti dimenzióiba, Turizmus Bulletin,19 (4), pp. 1-10.

FORNELL, C. (1992): A National Customer Satisfaction Barometer: the Swedish Experience, Journal of Marketing, 56 (1) pp. 6-21

GARZÓN, D.- NAVARRO, S. -ROIG-TIERNO, N. (2015): Co-creation in hotel-disable customer interactions. Journal of Business Research, 68: pp. 1630-1634.

GÁLNÉ, KUCSÁK K. (2008): A sötétség vándorai: A látássérültek turizmusának helyzete és esélyei Magyarországon. Turizmus Bulletin 12(2): pp. 53-59.

GONDA, T. - OROSZI, V. (2016): Az innováció értelmezése és gyakorlata a turizmusban Területfejlesztés és innováció 10 (1) pp. 3-19.

GONDA, T. - RAFFAY, Z. (2020): Egyedül nem megy- fogyatékkal élök utazási szokásainak vizsgálata egy nemzetközi felmérés eredményeinek tükrében. In: Csapó, J. - Csóka, L. (szerk.): Kreativitás, változás, reziliencia. III. Nemzetközi Turizmusmarketing Konferencia: Tanulmánykötet. Pécs, Magyarország: Pécsi Tudományegyetem Közgazdaságtudományi Kar, (2020) pp. 154-165. 12p.

GONDA, T. - CSAPÓ, J. (2019): A magyar lakosság utazási szokásai és az utazási döntéseiket befolyásoló információk forrásai. In: Csapó, J. - Gonda, T. - Raffay, Z. (szerk.): Turizmus, fogyasztás, generációk: II. Nemzetközi Turimus Konferencia: Tanulmánykötet. Pécs, Magyarország: Pécsi Tudományegyetem Közgazdaságtudományi Kar (PTE KTK), (2019) pp. 441 454., $14 \mathrm{p}$.

GONDOS, B. (2017): Turizmus és életminőség kapcsolata a mozgáskorlátozottak körében, tanulmány, Edutus Főiskola, Budapest, pp. 1-11.

GROTTE J. - KULCSÁR, N. (2018): Mit várunk a szállodáktól?- avagy a legmeghatározóbb fogyasztói szegmens számára értéket jelentő tényezők a szállodákban, Turizmus Bulletin, 18 (3) pp. 6-16.

KANDAMPULLY, J. - SUARTANTO, D. (2000): Customer loyalty in the hotel industry: the role of customer satisfaction and image. International Journal of Contemporary Hospitality Management, 12 (6), pp. 346-351

KARAKASNÉ-MORVAY, K. (2014): A minőségfejlesztés és a vendégelégedettség összefüggései a hazai wellness szállodákban, Doktori $(\mathrm{PhD})$ értekezés, Szent István Egyetem Gazdálkodás és Szervezéstudományok Doktori Iskola, Gödöllö, pp.1-224

KOVÁCS, T. -KOZÁK, A. (2016): Paraturizmus és konfliktusmenedzsment a szállodaiparban. Területfejlesztés és innováció2: pp. 18-26.

LENGYEL, M. (2008): TDM müködési kézikönyv. Heller Farkas Főiskola, Budapest 158 p.

LYU, S. O. (2017): Which accessible travel products are people with disabilities willing to pay more? A choice experiment. Tourism Management 59 pp. 404-412.

MESTER, CS. (2005): CRM - A vállalati hatékonyságnövelés régi-új eszköze, Magyar Minőség, 14 (10), pp. 24-29.

MICHALKÓ G. (2003): A fenntartható fejlődés ökoturisztikai aspektusai Magyarországon. Turizmus Bulletin. 7(4). pp. 13-21.

MICHALKÓ, G. (2012): Turizmológia: elméleti alapok. Akadémiai Kiadó, Budapest, 266 p.

POLINSZKY T. (1997): Az épített környezet. In: Chikán Cs., Józsa T. (szerk.): A mozgásfogyatékos emberek rehabilitációjának sokoldalú megközelítése. MEOSZ, Budapest.

RICKY, J. (2018): Considering service animals in tourism. Annals of Tourism Research pp. 1-2. STICKDORN, M.- ZEHRER, A. (2009): Service Design in Tourism: Customer Experience Driven Destination Management, De Thinking Service Re Thinking Design, First Nordic Conference on Service Design and Service Innovation, Researchgate, Oslo 
VEENHOVEN, R. (1996): The study of lifesatisfaction. In: Saris, W. E.,Veenhoven,R.,Scherpenzel, A. C.,Bunting, B. (eds.): A comparative studyof satisfaction with life in Europe. Eötvös University Press, Budapest. pp.11-48.

MCKERCHER, B., PACKER, T.L.- YAU M. K. (2004): Traveling with a Disability: More than an Acces Issue. Annals of Tourism Research, 4. pp. 946-960.

ZSARNÓCZKY, M. (2017): Accessible tourism in the European Union. In: Kamila Borseková, Anna Vanová, Katarína Vitálisová (szerk.) 6th Central European Conference in Regional Science „Engines of Urban and Regional Development”: Conference Proceedings. Banská Bystrica: Faculty of Economics, Matej Bel University in Banská Bystrica. pp. 30-39.

ZSARNÓCZKY, M. (2018): A kompatibilitás fontossága az akadálymentes turizmus speciális szegmensében, Konferenciakötet, Az Eszterházy Károly Egyetem Turizmus Tanszék alapításának 10. évfordulója alkalmából, pp. 1-10.

\section{Egyéb források}

\section{AKADÁLYMENTES TURIZMUS:}

http://szakmai.itthon.hu/akadalymentes-turizmus_( Letöltve:2020. 07. 02.)

MOTIVÁCIÓ ALAPÍTVÁNY ÉS A REVITA ALAPÍTVÁNY KUTATÓMÜHELYE (2009):

Fogyatékos emberek turisztikai szokásai és igényei.

http://revitaalapitvany.hu/letoltes/tanulmanyok/turizmus_vezetoi_osszefoglalo.pdf, (Letöltve:2020. 07. 02.) 